\title{
Research Based on the Theory of Value Chain to Governance and Upgrade of Local Tourism Industry Cluster
}

\author{
Ji Wen, Pingping Hou \\ Department of Tourism Management, Management School, Jinan University, Guangzhou, China \\ Email: twenji@jnu.edu.cn, grasshou@163.com
}

Received 22 February 2015; accepted 9 March 2015; published 13 March 2015

Copyright (C) 2015 by authors and Scientific Research Publishing Inc.

This work is licensed under the Creative Commons Attribution International License (CC BY). http://creativecommons.org/licenses/by/4.0/ cC) (i) Open Access

\begin{abstract}
Tourism Industry Cluster can adjust the structure of the tourism industry to achieve coordinated development of tourism in the development of the tourism industry. The cultivation of tourism industrial cluster is an effective regional tourism development strategy and effective way to improve the competitiveness of the regional tourism economy. The literature of governance and upgrading of tourism industry cluster is less. This study based on the value chain theory to explore the governance mechanism and countermeasures of local tourism industry cluster. This research used value chain management analysis framework of Kolinsky and Morris (2000) and put forward the supervision system of government legislation, internal governance and industry association in the value chain. This paper researches the local tourism industry cluster from three aspects of business, government and industry associations.
\end{abstract}

\section{Keywords}

Value Chain, Tourism Industry Cluster, Governance, Upgrade

\section{Introduction}

Tourism has become a new growth point of national economy, which is becoming more and more important in the social development. According to the World Tourism Organization prediction, China will become the world's first tourist reception country, the fourth country of outbound tourism and inbound tourism revenues could reach $\$ 63.5$ billion which will account for 8\% GDP by 2020. The rapid development of tourism industry in China, at the same time has problems. Tourism product structure is not perfect and unreasonable layout of regional tourism function. The homogenization of tourism products is serious. It is difficult to meet the demand of 
modern tourism consumers. Tourism industry is facing great pressure of structure adjustment and optimization and upgrading. Upgrading the tourism industrial cluster can adjust the tourism industry structure, and the coordinated and orderly development of tourism industry, to promote regional tourism industry to gain advantage in the fierce competition, such as: Overseas Chinese town of Shenzhen tourism industry cluster, Zhuhai hot spring tourism industry cluster, Alps fitness tourism industry cluster, Scenic tourist resort in tropical North Queensland region. They played an important role in the development of the tourism industry cluster of local tourism economy. The study is based on the value chain theory, and discusses the governance mechanism and upgrade countermeasures and upgrading of local tourism industry cluster.

There are five parts in this article. The first part of the article describes the current development of the local tourism industry cluster, from the perspective of industry clusters and value chains to clarify the paper's content and theme. The second part explains the theory foundation of the research, the theory of value chain and industrial cluster theory. The third and the fourth part is based on the value chain to explain the main contents of governance and upgrading of local tourism industry cluster from the three aspects of government, enterprise and tourism industries. At the end of this paper, the total research contents are summarized.

\section{Theories and Literature Review}

\subsection{The Theory of Value Chain}

In 1985, Harvard University Business School professor Michael Potter first put forward the theory of value chain [1]. Kaplinsky (2000) with Porter value chain as the foundation and taken the link between companies into account, then form the inter-industry value chain and within the industry value chain; The value chain is defined as: Products in the global scope, from conceptual design to the use and scrapped in the whole life cycle of all create value range of activities, including product design, production, marketing, distribution and on the enduser support and service etc. [2]. Various activities of the value chain can be contained within an enterprise, also can be dispersed among various enterprises, can be gathered within a particular geographic area, and can spread in the world. For the Value Chain Theory research focuses on three areas: One is the governance of value chain. Value chain governance refers to the organizational structure, the power distribution value chain organization, as well as the relationship between the various economic agents in the value chain.

Kaplinsky and Morris (2003) draw on the principle of separation of powers in Western society to propose an analytical framework of value chain governance, which is Value chain governance legislation, the implementation of governance and oversight management [3]. The second is to upgrade the value chain, mainly refers to the mechanism, the type and the path of industrial upgrading. The third is the production and distribution of economic rent in the value chain. Including the entry barriers, sources of economic rents generated (such as technical ability, organization ability, skills and marketing ability of core competence), the distribution of rent. The three aspects of value chain is the organic combination of governance, which is in the core position, it determines the distribution of the industry upgrading and rent in value chain. They provide a realistic theoretical framework to study the local industrial clusters in the value chain and the value of the potential acquisition.

\subsection{Tourism Industry Cluster}

The economist Alfred Marshall was the first proposed Industrial clusters (Indusrtial cluster) concept [4]. He pointed out that in the "principles of economics" book that industry cluster is the enterprise to seek external economy to a location agglomeration phenomenon [4]. Michael Potter pointed out that the industrial cluster is the relationship between competition and cooperation in a specific region, which geographically concentrated, interactive form relevance enterprise, specialized suppliers, financial institutions, service providers, manufacturers and other relevant bodies and other groups. It represents the emergence of a new form of space economic organization between market and hierarchy, includes a series of upstream, midstream and downstream industries and other enterprises or institutions [1].

The biggest characteristic of the tourism industry lies in its high relevance and comprehensiveness, relating to accommodation, travel shopping and entertainment etc, in order to obtain lasting competitive advantage which must have related and supporting industries complete support. Based on the concept of industrial cluster, many experts put forward the concept of tourism industry cluster. Office of Montana government's economic report definitions of Tourism Industrial Cluster: the tourism industry cluster refers to the concentration of the geo- 
graphical region which many travel companies similar or have related requirements and can generate external economies of scale and innovation of interest. Gong Shao Fang (2007) is defined the tourism industry cluster as: in a certain geographical area, around the local area tourism core attraction to form tourism enterprises as the mainstay, to assist service enterprises and organizations as a supplement and a phenomenon and tourism service system for the common goal of the tourism economic agglomeration, and the resulting business alliance, regional brand, innovation of tourism services as the tourism value chain [5]. Studies suggest that the tourism industry cluster based on a certain area to a tourist attraction as the core, supplied directly by the tourism industry as the foundation, under the protection of the relevant institutions and infrastructure, promote the coordinated development of tourism-related industries and supporting facilities and services, which is a complex system to promote tourism destination competitiveness through the close contact between tourism enterprise. The tourism industry cluster is concerned with specific industries within the region tourism economic ties, tourism industry value chain depends on the joint efforts and relationship of all tourism enterprises.

\section{Based on the Theory of Value Chain to Governance of Tourism Industry Cluster}

Scholars who study the tourism industry cluster governance are also less. Feng Weihong (2009) proposed to play the role of government departments in the tourism industry cluster development and governance [6]. The concurrence of coordination, cluster innovation, enterprise location space layout of tourism industry cluster enterprises mostly through government institutional arrangement, to play the role of government departments in the development of the tourism industry cluster and governance is very important. Ma Jianping (2012) in a case study of Hunan proposed the establishment of external governance, Formation of tourism industry cluster governance system of corporate governance and industry associations supervise governance [7]. Research based on the theory of value chain, drawing Kaplinsky and Morris (2003) analysis of the theoretical framework of value chain governance, proposed regulatory system of tourism industry value chain that government legislation, internal governance of enterprises and supervision of industry association [3]. In the governance system of government, enterprises and industry associations, the government's management is the most important and followed by the internal governance of enterprises.

\subsection{To Establish the Government Governance System}

3.1.1. The Government Plays the Leading Role to Establish and Improve Tourism Policies and Laws The development of tourism industry in a country or region good or bad is closely related to the construction of degree of the tourism laws and regulation. Establish and improve the regulations and legal system of tourism industry cluster is the key to guarantee and promote the healthy development of the tourism industry. Perfect law is the security to healthy development of the tourism industry. The government should promulgate a series laws and regulations to promote the development of tourism industry cluster and optimize the management of government. The government should optimize the layout of tourism industry cluster. Improve the tourism industry cluster development of property rights, financial, fiscal, legal and other aspects of sustainable policies. To promote the free flow of production factors, to break the monopoly market segmentation and region, improve the tourism industry operating environment. State and local governments should further improve the intellectual property laws and regulations of tourism resources, tourism service and tourism industry in tourism industry cluster. The development of tourism industry cluster gradually towards a standardized operation and high efficiency, then to realize the tourism industry cluster upgrade. Implementation of laws and policies of tourism industry cluster should be pay attention to the government's position and policy function boundary.

\subsubsection{Strengthening the Role of Government to Support and Promote the Development of Tourism Industry Cluster}

The correct guidance and cultivation of government is an important promoter to the regional tourism industry cluster formation and development. The government can not only create good hardware conditions for the development of regional tourism industry cluster, but also can provide good policy environment for cluster region tourism related enterprises. The government can through policy support to improve and create the formation and development of regional tourism industry cluster software environment and hardware facilities. The government to ensure supply of tourism infrastructure and strengthen the construction of information service platform. Guide the tourism enterprises and related enterprises or institutions gathered in a certain area on the geographical space. 


\subsubsection{Cultivate a Good Cultural Environment, Promoting Trust and Cooperation between the Enterprises in Cluster}

The government should base on trust to develop the regional cooperation culture, to strengthen the construction of social credit system. By cultivating trust based social cultural environment of which regional enterprises believe that cooperation will be higher than the breach of competition rules return, to promote fair competition among enterprises in the cluster. Local governments should use the power of public opinion, to guide the formation of cultural of tourism enterprise cluster. The functions of the government department link with social intermediary service organization of tourism industry cluster. Enterprises within the tourism industry cluster impartial and objective credit rating and announce to the inside and outside the cluster, the good credibility of tourism enterprises to vigorously promote, the credibility of the poor to give warning. The local government can use administrative means to intervention immoral behavior which endanger the overall reputation and interests of tourism industry cluster. Increase punishment cost of the moral hazard and the opportunism behavior of internal members in tourism industrial cluster.

\subsection{Strengthen Internal Governance of Tourism Industry Cluster and Enhance the Competitiveness of Tourism Enterprises}

Although the government is in the dominant position in the tourism industry cluster governance, due to staff of government departments lack of relevant expertise management knowledge of tourism industry cluster governance. In the governance process the resource-constrained and other reasons that led to the external governance of government to tourism cluster failure, that need to cultivate internal power of tourism industry cluster and keep the cluster development vitality. The government should raise awareness of cooperation of the tourism cluster enterprises, which including interaction and communication between the cluster of tourism enterprises and government departments. Tourism enterprises in the tourism industry cluster not only compete, but also cooperation, which including cooperation and innovation, joint marketing and joint training. The upstream and downstream enterprises in the same industry value chain also should strengthen cooperation. Large enterprises should give small businesses of capital, technology, information, networks, and other aspects of the market. Enhance market competitiveness and ability of associated small enterprises to resist risks. Companies in the same part of the industry value chain to maintain appropriate cooperation and competition, and resolutely stop the low price war. Tourism cluster enterprises should also keep open, to enhance the core competitiveness through integrated development, through communication with enterprise outside the cluster to get more resources to maintain good business innovation.

\subsection{Strengthening the Governance Role of the Tourism Industry Associations to Promote the Tourism Industry Cluster Upgrade}

\subsubsection{The Tourism Industry Association to Play the Role of Bridge}

Industry Association is the intermediary between government and business organizations, Tourism Industry Association is a non-profit social organization that enterprise self-education, self-management, self-service, regulate market behavior, maintaining corporate interests, promote social development of the industry corporate. The industrial cluster is usually concentrated and dominant an industry, so the industry association is particularly important for the management and development of industrial clusters. Give full play to the trade associations in the communication between government and enterprises, the development of industry standards, standardize the industry order, coordinate trade disputes and safeguard the interests of member, provide information to ensure fair trade and other aspects of unique role of industry. The industry association should play a coordinating role between government and enterprises to help enterprises solve practical problems faced by enterprises to safeguard their legitimate rights and interests. Tourism industry to organize tourism enterprises to carry out various activities, such as: To participate in the exhibition, conference and industry forum. This can't only get more advanced information about industry development, but also can improve the visibility of the industrial clusters. Given the political status to the core enterprise in tourism industry, enhance their sense of pride and honor, which can motivate the core enterprises better service the development of tourism industry cluster.

\subsubsection{Strengthen the Cluster Governance of Tourism Industry Association}

Strengthen the Cluster Industry Association Governance can promote the fostering and upgrading of tourism 
industry cluster to ensure the healthy and sustainable development of tourism industry cluster. The cluster governance of travel industry association can effectively restrain and avoid homogenization, low level of vicious competition of enterprises in tourism industry clusters. It also can effective regulation of the market competition and promote the harmonious and orderly development of industrial cluster. The key of cluster governance of tourism industry association is the formulation of the articles of tourism industry association cluster governance and improve the incentive and restraint mechanism of industry cluster governance, in which the especially important is incentive mechanism of industry cluster governance. Cluster governance charter of Tourism Association to provide a code of conduct of the framework and guidelines for the enterprise. Good monitoring mechanism can reduce the external behavior of enterprises. Improve internal incentive mechanism can better guide the tourism enterprises beneficially to the development of industrial cluster governance.

\section{Based on the Value Chain of the Tourism Industry to Upgrade Strategies}

From the perspective of value chain to tourism industry cluster upgrading means to change the development model, morphology and pattern of tourism industry. From low-end extensive tourism transfer into intensive mode and both the transition from a simple expansion of scale to pay attention to the scale and benefit, realizing tourism industry economic function transfer into comprehensive function of tourism industry. To promote the local tourism industry cluster in tourism value chain of tourism industry in quality and benefit. The core of the upgrade of tourism industry cluster is to optimize the industrial structure. The ultimate goal is to improve the quality and efficiency of tourism industry. Achieve a comprehensive upgrade of tourism.

Zhong Ling (2013) based on the value chain theory to research on the upgrading of Hainan tourism industrial and puts forward to improve efficiency and quality of tourism industry and professional skills of tourism staff [8]. Yuan Jinming (2007) based on value chain theory has conducted the research on the forest tourism industry in Hunan province, According to three levels of forest tourism destination (and products), the industrial cluster and the tourism enterprise group to propose upgrade strategy of value chain of Hunan forest tourism industry [9]. The research from three aspects of enterprise, government and industry association and put forward the upgrading strategies of local tourism industry cluster.

\subsection{Upgrading Strategy of Enterprises in Tourism Industry Cluster}

\subsubsection{The Upgrade Strategy of Product}

The local tourism industry cluster mainly composed of many small and medium-sized tourism enterprises, most enterprises do not have their own product innovation ability, such as travel agencies to line combination of tourism products, which is usually produced by large tourism enterprises and small tourism enterprises mainly imitation of other enterprise products to survive. Large number of homogenization tourism products to create vicious competition of price in tourism industry clusters. The production of the products with independent intellectual property and the implementation of differentiated products competitive strategy is the key to upgrade the local tourism industry cluster. To expand upstream and downstream industries in the tourism industrial clusters to extend the industrial chain

\subsubsection{To Build the Brand of the Local Tourism Industry Cluster}

In the national scope which lack of tourism industrial cluster brand with scale and influence in the national scope, required to establish brand of local tourism industry cluster. Through good faith cooperation of local tourism enterprises to upgrade the overall tourism industry added value of three aspects of the influence, scale and grade. Build local tourism industry cluster brand and establish. To establish leading brand have radiation force to other tourism companies, which is conducive to the establishment of local tourism brand. On the other hand, lead the establishment and experience management of brand can provide a sample for the study of other companies within the cluster established brands. This will help expand the brand in the local tourism industry cluster, promote enterprise cluster learning each other and promote each other, so as to enhance the competitiveness of the local tourism industry cluster.

\subsection{Government Strategy in the Local Tourism Industry Cluster}

\subsubsection{Develop the Tourism Industry Cluster Strategy, Guide Industry Cluster Area Division}

The government of the regional industrial layout according to the regional comparative advantages in resources 
and space condition, only those regions with the tourism industry and competitive advantage is suitable for the development of tourism industry cluster. The planning of regional tourism development strategy of industry cluster to promote regional specialization and prevent the regional tourism industry cluster convergence. Deepening specialization will increase the competitiveness of local tourism. When professional degree is low, the enterprises similar to each other with the alternative strong and mutual inhibition; High degree of specialization, the big differences are complementary and promote each other. So in the process of cultivate the tourism industry cluster that must strengthen specialization of tourism industry cluster.

\subsubsection{Support Related Auxiliary Industry Development to Cultivate and Improve the Tourism Industry Supporting System}

The biggest characteristic of the tourism industry lies in its high relevance and comprehensiveness, relating to accommodation, travel shopping and entertainment etc, in order to obtain lasting competitive advantage which must have related and supporting industries complete support. The government around dominant industry chain cultivation and improvement supporting system of local tourism industry to form competitive characteristic of tourism industry system, and enrich tourism products system, improve the tourism function to make the tourism industry have fast aggregation effect. Government should promote tourism in conjunction with agriculture, industry, commerce and cultural industries to form matching system of the tourism industry. The government will also vigorously the construction of hard environment, improve traffic, water and electricity, communications and other infrastructure, reduce the daily operation of enterprise cost, to provide convenience for the development of enterprises, reduce the hardware barriers in the process of form tourism industry cluster.

\subsubsection{The Government Should Increase the Development of Human Resources and the Optimal Allocation of Human Resources}

Good human resource allocation lay a good foundation for the talents of industrial cluster upgrading. The government should increase the tourism professional introduction efforts, attracting the talents with preferential policies, retain talent. The government introduction a number of professional tour managers and technical experts with a pioneering spirit, it should focus on enterprises senior management person who can operate tourism. Tourism talents should familiar with international market rules with exquisite technology and high level tourism professional. Government-run public tourism training institutions to foster tourism specialization talent market, which provide a convenient choice for corporate human resources. Tourism industry is a labor-intensive industry, greater demand for tourism talents. Cooperation with local universities and vocational training institutions to carry out tourism professionals, Cooperation with industry associations, relying on universities, offering a variety of levels, personnel training courses of different lengths of time, training can be tailored according to the needs of tourism businesses.

\subsection{Play Information Intermediary Role of Industry Association}

Tourism industry association as a collective organization plays an indispensable role in the coordination between buyers, traders and the local tourism industry and maintaining interest of local tourism industry, which also play an important role in promoting the upgrading of industrial organizational elements. Tourism industry associations should timely feedback to the government, making government policies more in line with the demand of enterprise and the market. Under the government's macroeconomic policy guidelines, tourism industry associations should play an active role to cooperation with relevant community organization, organize the majority of tourism enterprises to participate in self-discipline, to learn advanced experience and management from international cooperation to promote the healthy development of the industry.

\section{Conclusion}

The government should take the development of the tourism industry cluster as a new train of thought to develop local tourism industry, take full advantage of the local tourism industry to foster innovation system of local tourism industry, to promote the orderly development of tourism industry and improve the local tourism industry cluster competitiveness, as well as the sustainable development of enterprises. This research based on the value chain theory discusses the governance mechanism and governance countermeasures and upgrading of local tourism industry cluster. This paper uses the value chain theory analysis framework of Kaplinsky and Morris 
(2000) to put forward the governance system of tourism industry cluster. There are legislation governance of government, internal governance of enterprise and industry association executive governance. The study is based on three aspects of enterprise, government and industry association to put forward the upgrading strategy of local tourism industry cluster. The economic and social development can promote the vigorous development of tourism industry cluster. The competitiveness of tourism destination will continuously upgrade.

\section{References}

[1] Porter, M. (2002) Competitive Advantage of Nations. Huaxia Publishing House, Beijing.

[2] Kaplinsky, R. (2000) Spreading the Gains from Globalisation: What Can Be Learned from Value Chain Analysis. Journal of Development Studies, 37, 117-146. http://web.b.ebscohost.com/ehost/pdfviewer/pdfviewer?sid=a2872187

[3] Kaplinsky, R. and Morris, M. (2003) Governance Matters in Value Chains. Developing Alternatives, 9, 11-18. http://eprints.brighton.ac.uk/4401/

[4] Marshall, A. (2012) Principles of Economics. Hunan Art Publishing House, Changsha.

[5] Gong, S.F. (2007) A Preliminary Study on the Development Strategy of Regional Tourism Industry Clusters. Journal of Zhongzhou, 4, 71-73. http://www.cnki.net/KCMS/detail/detail.aspx

[6] Feng, W.H. and Miao, C.H. (2009) The Domestic and Foreign Research Review on Tourism Industry Cluster. Human Geography, 1, 16-21. http://www.cnki.net/KCMS/detail/detail.aspx

[7] Ma, J.P. (2012) Minority Areas of Tourism Industry Cluster Governance Research-Taking Hunan Xiangxi Autonomous Prefecture as an Example. Guizhou Ethnic Studies, 2, 124-129. http://www.cnki.net/KCMS/detail/detail.aspx

[8] Zhong, L. (2013) Research on the Strategy of Hainan Tourism Industry Upgrading in Global Value Chain. Ph.D. Thesis, Hainan University, Haikou.

[9] Yuan, J.M. (2007) The Study on the Forest Tourism Industry in Hunan Province Based on the Theory of Value Chain. Ph.D. Thesis, Central South University of Forestry and Technology, Changsha. 